\title{
Temporal dynamics of the phytoplankton community associated with environmental factors and harmful algal blooms in Acapulco Bay, Mexico
}

\author{
Víctor A. Cervantes-Urieta ${ }^{1}$, Ma. Nieves Trujillo-Tapia ${ }^{2}$, Juan Violante-González ${ }^{3}$ \\ Giovanni Moreno-Díaz ${ }^{3}$, Agustín A. Rojas-Herrera ${ }^{3}$ \& Víctor Rosas-Guerrero ${ }^{4}$ \\ ${ }^{1}$ Maestría en Recursos Naturales y Ecología, Facultad de Ecología Marina \\ Universidad Autónoma de Guerrero, Guerrero, México \\ ${ }^{2}$ Instituto de Ecología, Laboratorio de Biotecnología Ambiental \\ Universidad del Mar, Puerto Ángel, Oaxaca, México \\ ${ }^{3}$ Facultad de Ecología Marina, Universidad Autónoma de Guerrero, Guerrero, México \\ ${ }^{4}$ Escuela Superior de Desarrollo Sustentable, Universidad Autónoma de Guerrero \\ Tecpan de Galeana, México \\ Corresponding author: Agustín A. Rojas-Herrera (rojashaa@gmail.com)
}

\begin{abstract}
The phytoplankton community's temporal variability associated with environmental factors and harmful algal blooms in Acapulco Bay was analyzed. Phytoplankton samples were taken monthly at three sites (MSL: Morro de San Lorenzo, CDO: Casa Díaz Ordaz, and PP: Playa Palmitas) over 11 months in 2018. The physical and chemical variables of surface water were measured in situ, and the composition and community structure of phytoplankton were analyzed. The physical and chemical characteristics studied varied significantly. The highest temperatures were obtained in September and October (September: $29.6 \pm 3.58^{\circ} \mathrm{C}$, October: 34.61 $\pm 1.83^{\circ} \mathrm{C}$ ), whereas the highest salinities and chlorophyll- $a$ concentrations occurred from February to May (salinity: $34.06 \pm 0.38$, chlorophyll- $a$ : $2.73 \pm 0.15 \mu \mathrm{g} \mathrm{L}^{-1}$ ). The highest oxygen concentrations were recorded during the rainy season (June $91.8 \%$ and December 100\%). A total of 201 phytoplankton species were identified: 94 diatoms, 101 dinoflagellates, 4 cyanobacteria, and 2 silicoflagellates. Diatoms dominated during the rainy season, whereas dinoflagellates dominated during the dry season (June to December). A total of 17 harmful species were identified; four toxin-producing species included a diatom genus (Pseudonitszchia sp.) and three dinoflagellate species (Gymnodinium catenatum, Dinophysis caudata, and Phalacroma rotundata). One species that produces oxygen reactive species and hemolysis (Margalefidinium polykrikoides) caused a harmful algal bloom at the CDO and PP stations. The temperature is one of the most critical factors for its bloom in October.
\end{abstract}

Keywords: phytoplankton; harmful algal blooms; temporal variation; composition; Acapulco Bay

\section{INTRODUCTION}

Marine phytoplankton constitutes an essential component of marine ecosystems. They are autotrophic organisms at the base of the trophic web that transfer energy to other trophic levels and comprise over $90 \%$ of existing organic matter. They also contribute to regulating biochemical cycles and the stability of multiple aquatic ecosystems (Margalef 1981, Falkowski $\&$ Raven 2007). The structure and composition of marine phytoplankton depend on each species' presence and relative abundance, which can vary temporally due to differences in the relative rates of increase and decrease of each population (Shayestehfar et al. 2010).

Approximately 1488 species of marine phytoplankton have been identified in the waters of the Pacific Ocean and Gulf of Mexico; they have been classified into 211 genera, representing $33-42 \%$ of the total estimated for the entire world (Hernández-Becerril 2014). In particular, 168 genera and 641 species of marine phytoplankton were reported for Acapulco Bay from 2000 to 2009 (Meave del Castillo et al. 2012). On the other hand, Rojas-Herrera et al. (2012) and MorenoDíaz et al. (2015a,b) documented approximately 65 to

Corresponding editor: José Luis Iriarte 
87 species from 2009 to 2012, which shows significant variability in the phytoplankton species composition of Acapulco Bay over time.

Variability in species composition could respond to complex interactions between physical, chemical, and biological factors (Shevchenko et al. 2018). Moreover, rates of variation fluctuate in intensity and frequency (Reynolds 1989) due to phytoplankton's high metabolic activity in response to several environmental stress scenarios (Fogg 2001). As primary producers, phytoplankton species are sensitive to the increase and decrease in nitrogenous compounds and phosphates, even in some oligo-elements (Griffith \& Gobler 2020), increasing population numbers known as algal blooms. Population increases act as a biological carbon bomb that helps mitigate the greenhouse effect, increases the production of dimethylsulphide (DMS), and creates high oceanic production pulses (Carreto-Iraurgui 1989).

Although most algal blooms are harmless (GárateLizárraga \& Muñetón-Gómez 2006, Gárate-Lizárraga et al. 2009), some are not, and have been called harmful algal blooms (HAB). They are characterized by their negative impact on public health, agriculture, the environment, and recreational activities. These HABs tend to modify the ecological dynamics of aquatic environments, causing anoxia, hyperoxygenation, and decreases in $\mathrm{pH}$, among other effects; some adverse effects are directly related to the harmful and toxic phytoplankton population growth (Granéli \& Turner 2006).

Approximately $90 \mathrm{HAB}$ events were reported from 2000 to 2015 for the coast of Guerrero, and in particular, for Acapulco Bay, 77 of these events were harmful, and 11 were toxic $\mathrm{HAB}$ events, produced by 40 species: 21 diatoms and 19 dinoflagellates (Meave del Castillo \& Zamudio-Resendiz 2018). The composition and structure of the marine phytoplankton community in Acapulco Bay could vary in time and space and the co-occurrence of harmful or toxic species (Gárate-Lizárraga et al. 2008, 2009, 2013, 2016, Meave del Castillo et al. 2012, Rojas-Herrera et al. 2012, Moreno-Díaz et al. 2015a,b). Therefore, the temporal analysis of phytoplankton communities is highly relevant to provide information for preventing $\mathrm{HAB}$ and monitoring phytoplankton communities associated with $\mathrm{HAB}$ events, particularly in coastal environments where several economic and recreational activities are carried out. Therefore, the present study's objective was to evaluate the phytoplankton community's temporal variability associated with environmental factors and HAB events in Acapulco Bay during the 2018 annual cycle.

\section{MATERIALS AND METHODS}

\section{Study area and sampling stations}

Acapulco Bay is located on the coast of the state of Guerrero in southern Mexico (16 $\left.51^{\circ} 42 " \mathrm{~N}, 9^{\circ} 53^{\prime} 11^{\prime \prime W}\right)$, in the Mexican Transitional Pacific (CONABIO, 2007). The bay mouth is approximately $2.7 \mathrm{~km}$ long, extending $5.5 \mathrm{~km}$ into the bay, with depths ranging from 0 to $50 \mathrm{~m}$. The prevailing climate in the region is rainy tropical (Aw); in summer, the average precipitation is above $100 \mathrm{~mm}$ between June and October, and precipitation is below $4 \mathrm{~mm}$ between February and April (Mayo-Vera 2004). Temperatures above $18^{\circ} \mathrm{C}$ occur year-round. Phytoplankton samples were collected at three sampling sites: MSL: Morro de San Lorenzo, CDO: Casa Díaz Ordaz, and PP: Playa Palmitas (Fig. 1).

\section{Sample collection and environmental variables}

Surface tows of 5 min duration were undertaken at each site, using a $1.29 \mathrm{~m}$ long plankton net with $43 \mu \mathrm{m}$ mesh size. Samples were placed in $500 \mathrm{~mL}$ polyethylene bottles and fixed in $4 \%$ formaldehyde. Samples were obtained monthly during 11 months of the 2018 annual cycle. Environmental variables (physical, chemical, and biological) such as surface temperature $\left({ }^{\circ} \mathrm{C}\right)$, salinity, dissolved oxygen (\% saturation), and chlorophyll$a\left(\mu \mathrm{g} \mathrm{L}^{-1}\right)$ were measured in situ using a YSI v2-4 6600 multiparameter probes.

\section{Phytoplankton identification, composition, and structure}

Specimen identification was based on cellular morphology and undertaken to species level, using specialized literature (Cupp 1943, Balech 1988, LiceaDurán et al. 1995, Hasle \& Syvertsen 1996, Moreno et al. 1996, Throndsen 1997). Phytoplankton composition was analyzed based on the relative species abundance, using randomly counting the first 500 cells for each sampling site (Rojas-Herrera et al. 2012, Moreno-Díaz et al. 2015b). The community structure was estimated using the following community descriptors: total number of species, Shannon-Weaver diversity index (H) (Margalef 1981), Pielou's evenness index (J) (Pielou 1969), and Berger Parker dominance index (BPI) (Magurran 2004).

\section{Data analysis}

Permutation analysis of variance (PERMANOVA) was undertaken to test for significant differences in the abundance of the different phytoplankton groups (diatoms, dinoflagellates, cyanobacteria, and silicoflagellates) and the physical, chemical, and biological variables during the sampled months, using the software 


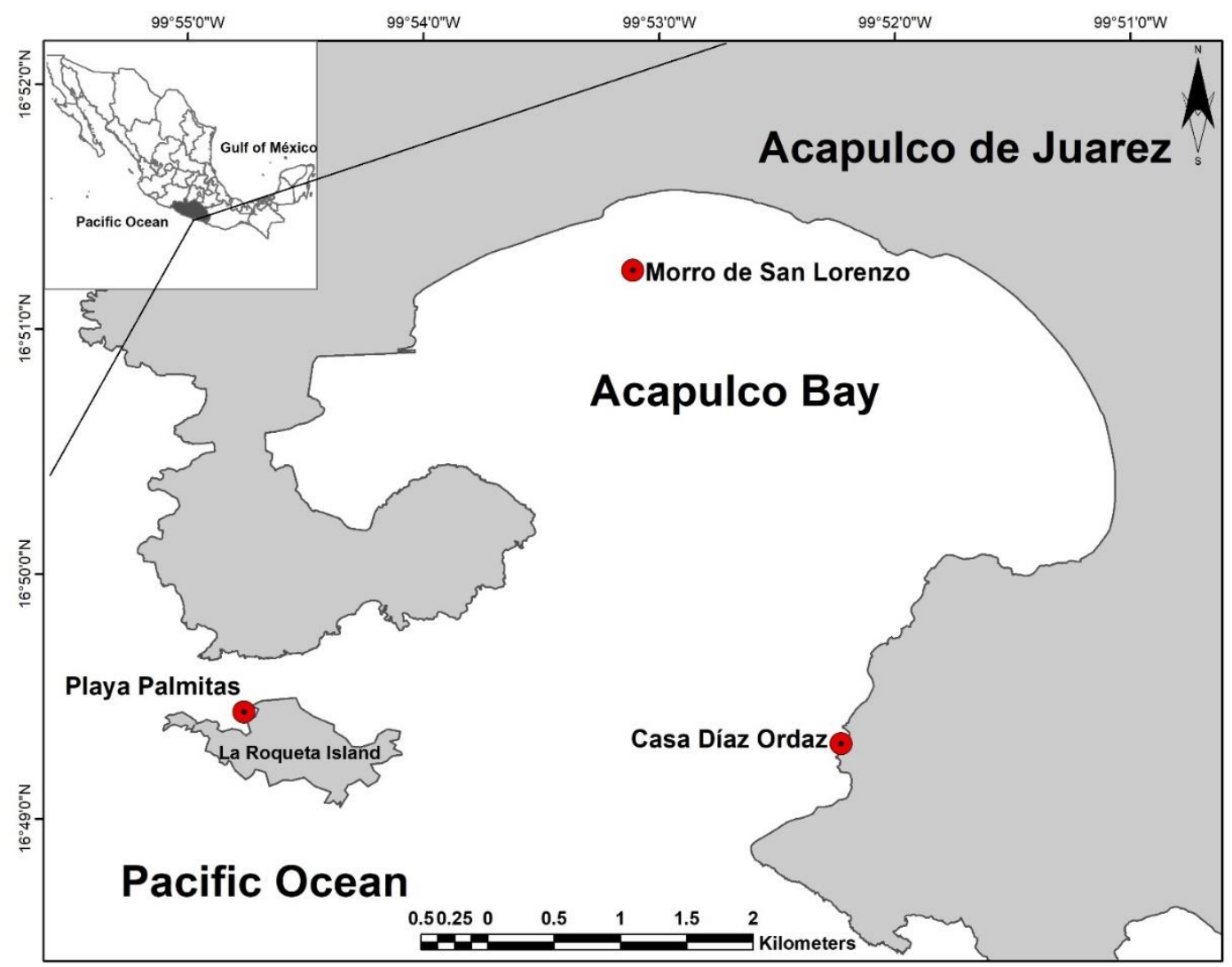

Figure 1. Location of the sampling area in Acapulco Bay, Guerrero, Mexico.

Paleontological Statistics (PAST 3.23) (Anderson 2001). A principal component analysis (PCA) was undertaken to visualize the temporal distribution (among months) and the affinity between the environmental variables and the sampled sites, using PRIMER v.6.1.6.

Temporal differences in the phytoplankton community structure were analyzed with non-parametric Kruskal-Wallis $H$ and multiple ranks tests at a significance level $\alpha=0.05$ (Zar 1999), using the package Infostat $2018 \mathrm{Web}$ [www.infostat.com.ar/]. A non-parametric Olmstead-Tukey test for association bivariate graphic analysis was applied to prioritize the phytoplankton species' dominance, classifying species as dominant (abundant and frequent), frequent (not very abundant and frequent), occasional (abundant and low frequency), or rare (low abundance and low frequency), using IBM-SPSS Statistics 23.

The temporal similarity in species composition between the sampled months was analyzed with a Cluster analysis, using the group average method as a grouping measure. A multidimensional non-metric scaling analysis (nMDS) was used to illustrate the similarity in species composition between sampled sites based on the Cluster submodule. The Bray Curtis similarity matrices of the original data were transformed logarithmically $[\log (\mathrm{x}+1)]$ using PRIMER v.6.1.6.

The relationship between the dominant phytoplankton species and the environmental variables was assessed with a gradient analysis, using an ordination based on the canonical correspondence analysis (CCA). A Monte Carlo permutation test was used to assess whether the first axes' eigenvalues and the correlation values between the species and the environmental variables obtained with the CCA were statistically significant at a significance level $\alpha=0.05$. The gradient length was previously estimated with a restricted gradient analysis (DCA) using CANOCO v.4.5.

\section{RESULTS}

\section{Environmental variables}

The average values of the physical, chemical and biological variables are shown (Table 1). The multivariate variance analysis showed significant differences between the analyzed months in the environmental variables (PERMANOVA, $P=0.0001$ ). The PCA showed that the months and sites corresponding to the 
Table 1. Temporal variation of the physical, chemical, and biological variables of Acapulco Bay surface water (mean \pm standard deviation). **Indicates statistically significant differences $(P=0.001)$.

\begin{tabular}{lcccl}
\hline Months & $\begin{array}{c}\text { Temperature } \\
\left({ }^{\circ} \mathrm{C}\right)\end{array}$ & \multicolumn{1}{c}{ Salinity } & $\begin{array}{c}\text { Chlorophyll- } a \\
(\mu \mathrm{g} \mathrm{L})\end{array}$ & $\begin{array}{c}\text { Oxygen } \\
(\%)\end{array}$ \\
\hline February & $27.4 \pm 0.39$ & $33.31 \pm 0.27$ & $1.96 \pm 0.40$ & 70.1 \\
March & $24.95 \pm 0.8$ & $33.16 \pm 0.03$ & $2.56 \pm 0.2^{* *}$ & 76 \\
April & $25.54 \pm 0.15$ & $33.21 \pm 1.11$ & $2.73 \pm 0.15^{* *}$ & 72.1 \\
May & $29.55 \pm 0.5$ & $34.06 \pm 0.38^{* *}$ & $1.86 \pm 0.21$ & 64.2 \\
June & $28.46 \pm 2.66$ & $28.73 \pm 3.27$ & $1.23 \pm 0.49$ & $100^{* *}$ \\
July & $25.53 \pm 0.25$ & $29.56 \pm 0.23^{* *}$ & $0.63 \pm 0.6$ & 77.3 \\
August & $25.66 \pm 0.50$ & $28.82 \pm 5.73$ & $0.76 \pm 0.15$ & $35.12^{* * *}$ \\
September & $29.6 \pm 3.58$ & $31.52 \pm 0.91$ & $1.1 \pm 0.26$ & $38.3^{* * *}$ \\
October & $34.61 \pm 1.83^{* *}$ & $30.31 \pm 0.92$ & $0.76 \pm 0.06$ & 56.9 \\
December & $24.4 \pm 0.26^{* *}$ & $31.62 \pm 1.57$ & $0.36 \pm 0.15^{* *}$ & 91.8 \\
\hline
\end{tabular}

dry season (January to May) were associated with high salinities and high chlorophyll- $a$ concentrations. In contrast, the rainy season months (June to December) were associated with temperature and dissolved oxygen (Fig. 2). Temperature values varied significantly from $24.4 \pm 0.26$ to $34.61 \pm 1.83^{\circ} \mathrm{C}$; October was the hottest month $\left(>30^{\circ} \mathrm{C}\right)$, and December was the coldest month $\left(<25^{\circ} \mathrm{C}\right)$. Salinity was significantly higher in May $(34.06 \pm 0.38)$, whereas June had the lowest salinity $(28.73 \pm 3.27)$. Dissolved oxygen ranged from $34.12 \%$ in August to $100 \%$ in June, whereas the highest chlorophyll- $a$ values occurred in March and April (2.56 \pm 0.2 and $2.73 \pm 0.15 \mu \mathrm{g} \mathrm{L}^{-1}$, respectively) and the lowest occurred in December $\left(0.36 \pm 0.15 \mu \mathrm{g} \mathrm{L}^{-1}\right)$.

\section{Phytoplankton composition and structure}

Species composition varied significantly during the studied months (PERMANOVA, $P=0.0001$ ). The Cluster analysis showed that similarity in species composition was above 65\% in May and June (Fig. 3a). The nMDS ordination created three groups with $31 \%$ similarity among them. The first group corresponded to the rainy season (January to May) with low similarity (35\%) between sites and months. The second group corresponded to the dry season (June to December) with more significant similarity (67\%). The third group comprised the CDO and PP stations with 52\% similarity; both were associated with a HAB event in October (Fig. 3b).

A total of 201 phytoplankton species were identified during the 2018 annual cycle (Table 2). There were 101 dinoflagellates species, 94 diatoms, 4 cyanobacteria, and 2 silicoflagellates. Diatoms represented over $60 \%$ of the total in terms of abundance (10,987 ind) and dominated during the rainy season (July to September). Dinoflagellates represented 29\% of the total (4587) and dominated during the dry season (January to May) (Fig.



Figure 2. Principal component analysis (PCA) using the different physical and chemical variables present in Acapulco Bay. MSL: Morro de San Lorenzo, CD: Casa Díaz Ordaz, and PP: Playa Palmitas.

4). Fourteen species dominated numerically in relative abundance during the annual cycle, including eight diatom species (Chaetoceros lorenzianus, Chaetoceros spp., Climacodium frauenfeldianum, Detonula pumila, Leptocylindrus danicus, Pseudo-nitzschia sp., Skeletonema costatum, and Thalassionema nitzschioides). These species represented $57 \%$ of the species with relative abundance ranging from 13 to $80 \%$. Five dinoflagellate species (Dinophysis caudata, Diplopsalopsis bomba, Diplopsalis lenticula, Margalefidinium polykrikoides, and Noctiluca scintillans) and one diazotrophic cyanobacterium (Trichodesmium erythraeum) represented 36\% of abundance (Table 3). Total species richness varied significantly over time $(H=15.60, P<$ $0.05)$, from 102 species in April to 32 species in September. The greatest species richness values were found at PP (44.8 species) and CDO (34.8 species). The 

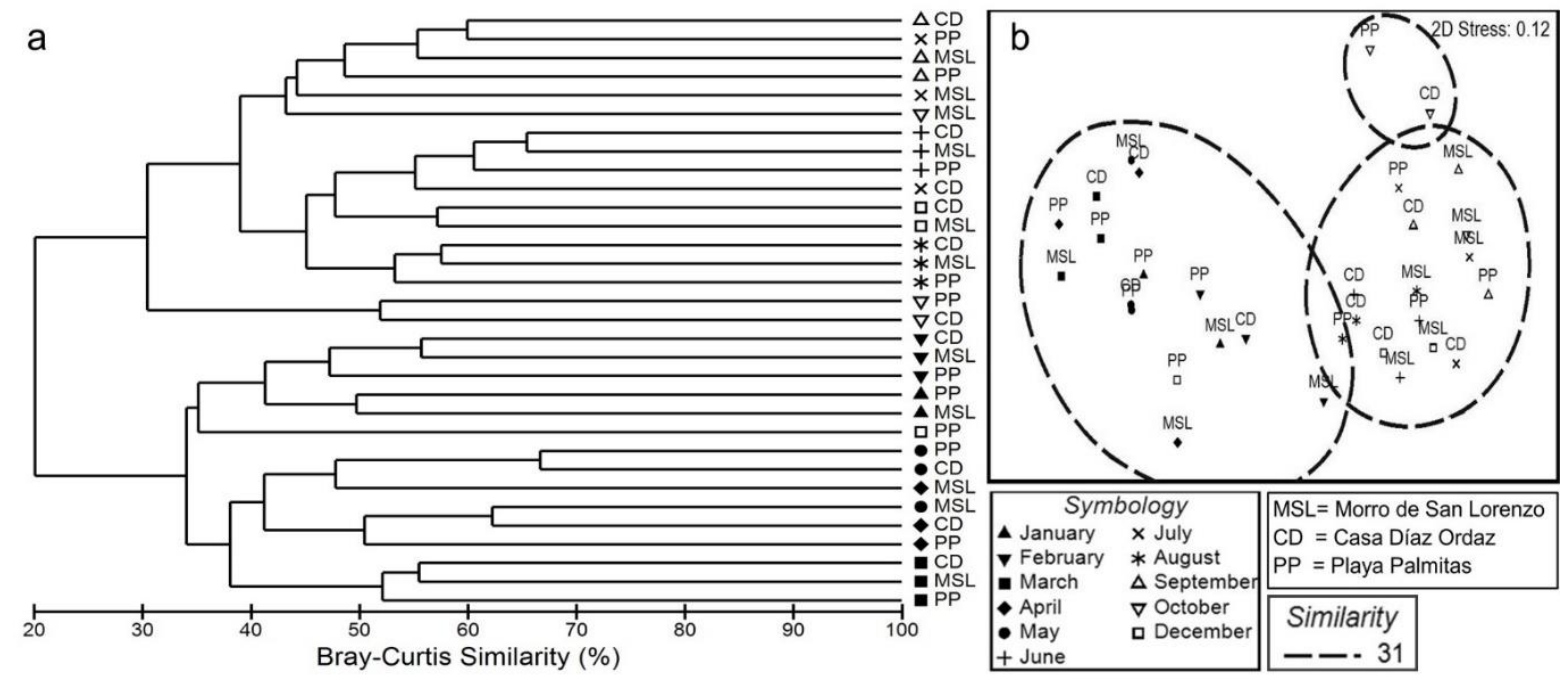

Figure 3. Temporal variability of phytoplankton abundance. a) Cluster analysis and b) non-metric multidimensional scaling (nMDS) based on the logarithmic transformation of abundance data by applying the Bray-Curtis similarity index and the average group link.

Table 2. Species richness and phytoplankton composition (\%) in Acapulco Bay.

\begin{tabular}{llcccc}
\hline \multirow{2}{*}{ Phyla } & \multicolumn{1}{c}{ Class } & $\begin{array}{c}\text { Species } \\
\text { richness }\end{array}$ & $\begin{array}{c}\text { Composition } \\
(\%)\end{array}$ & $\begin{array}{c}\text { Total } \\
\text { individuals }\end{array}$ & $\begin{array}{c}\text { Relative } \\
\text { abundance }(\%)\end{array}$ \\
\hline Bacillariophyta & Bacillariophyceae & 19 & 9.4 & 896 & 5.6 \\
& Coscinodiscophyceae & 26 & 12.93 & 1266 & 7.91 \\
& Mediophyceae & 49 & 24.37 & 8825 & 55.15 \\
\hline Subtotal & & & & 10987 & 68.66 \\
\hline Dinophyta & Dinophyceae & 101 & 50.24 & 4587 & 28.66 \\
Cyanophyta & Cyanophyceae & 4 & 1.99 & 418 & 2.61 \\
Ochrophyta & Dictyochophyceae & 2 & 0.9 & 8 & 0.05 \\
\hline Total & & 201 & 100 & 26987 & 100 \\
\hline
\end{tabular}

diversity index varied significantly over time, with values ranging from 0.90 to $3.22(H=26.26, P=$ $0.003)$; evenness ranged from 0.3 to $0.8(H=25.75, P$ $=0.004)$. The greatest diversity occurred in April (3.12) and May (3.22), and the lowest diversity occurred from July to October (0.90 to 1.49$)$. These values were significantly correlated with the months of greatest dominance $(H=25.33, P=0.004)$; the greatest dominance (0.80) was obtained in July, and the lowest (0.17) was obtained in May (Fig. 5).

The bivariate graph analysis showed 33 dominant species (i.e. abundant and frequent), of which diatoms represented 52\% (Fig. 6); eight genera were the most representative (Chaetoceros, Climacodium, Leptocylindrus, Pseudo-nitzschia, Skeletonema, Stephanopyxis, Streptotheca, and Thalassionema). Forty-eight species were classified as frequent (i.e. not very abundant and frequent), mainly from the dinoflagellate group, with 24 species (50\%) distributed in 11 genera (Amphisolenia, Ceratocorys, Gonyaulax, Ornithocercus, Phalacroma,
Podolampas, Prorocentrum, Protoperidinium, Pyrocystis, Pyrophacus, and Tripos). Three species were classified as occasional (abundant and not frequent), including one diatom (Detonula pumila) and two dinoflagellates (Diplopsalopsis bomba and Margalefidinium polykrikoides). A total of 117 species were classified as rare (low abundance and low frequency), 54 of which corresponded to diatoms and 61 to dinoflagellates.

The CCA applied to the most dominant species and environmental variables associated significantly $(F=$ $1.91, P=0.004$ ) two phytoplankton species (one diatom Skeletonema costatum and one dinoflagellate Margalefidinium polykrikoides) with the highest temperature $\left(34^{\circ} \mathrm{C}\right)$, mainly in October. The latter species was associated with the HAB event, whereas the lowest temperatures and the maximum oxygen levels were associated with Chaetoceros spp. and Pseudo-nitzschia spp. Four dinoflagellate species (Dinophysis caudata, Diplopsalopsis bomba, Diplopsalis 




Figure 4. Temporal variation of the main phytoplanktonic groups of Acapulco Bay.

Table 3. Dominant species of the phytoplankton community in Acapulco Bay, Mexico.

\begin{tabular}{|c|c|c|c|c|}
\hline \multirow{2}{*}{ Month } & \multirow{2}{*}{ Dominant species } & \multicolumn{3}{|c|}{ Relative abundance (\%) } \\
\hline & & Morro de San Lorenzo & Casa Díaz Ordaz & Playa Palmitas \\
\hline January & Climacodium frauenfeldianum & 3.8 & 0 & 23.4 \\
\hline February & Thalassionema nitzschioides & 56 & 40.4 & 17.6 \\
\hline \multirow{3}{*}{ March } & Dinophysis caudata & 9.4 & 29 & 6.8 \\
\hline & Diplopsalopsis bomba & 16.6 & 22.4 & 6.6 \\
\hline & Noctiluca scintillans & 1.6 & 6.2 & 37 \\
\hline \multirow{2}{*}{ April } & Trichodesmium erythraeum & 23 & 0.6 & 0.4 \\
\hline & Diplopsalis lenticula & 0.1 & 12 & 16.2 \\
\hline \multirow{4}{*}{ May } & Leptocylindrus danicus & 0 & 17.8 & 4.6 \\
\hline & Trichodesmium erythraeum & 0 & 8.6 & 7.6 \\
\hline & Diplopsalis lenticula & 16 & 6.8 & 4.6 \\
\hline & Detonula pumila & 21.4 & 6.2 & 0 \\
\hline \multirow{2}{*}{ June } & Chaetoceros spp. & 31.4 & 37.4 & 62.6 \\
\hline & Chaetoceros lorenzianus & 31 & 20.4 & 8.4 \\
\hline July & Chaetoceros spp. & 91.4 & 72.6 & 76 \\
\hline \multirow{2}{*}{ August } & Pseudo-nitzschia sp. & 19.2 & 18.6 & 3.6 \\
\hline & Chaetoceros spp. & 64 & 62.6 & 66 \\
\hline \multirow{2}{*}{ September } & Chaetoceros spp. & 1 & 74.2 & 26.6 \\
\hline & Skeletonema costatum & 77.2 & 5.2 & 56 \\
\hline \multirow{2}{*}{ October } & Chaetoceros spp. & 63.4 & 27.4 & 14 \\
\hline & Margalefidinium polykrikoides & 0 & 59 & 72.4 \\
\hline December & Chaetoceros spp. & 38.4 & 57 & 9.4 \\
\hline
\end{tabular}

lenticula, and Noctiluca scintillans), four diatoms (Climacodium frauenfeldianum, Detonula pumila, Leptocylindrus danicus, and Thalassionema nitzschioides), and one cyanobacterium (Trichodesmium erythraeum) showed optimum development at the highest salinity concentrations (Fig. 7).

\section{Harmful phytoplankton species}

Seventeen harmful phytoplankton species with the potential to create $\mathrm{HAB}$ events were found in this study.
Seven potentially toxic species, including two diatoms (Pseudo-nitszchia pungens and Pseudo-nitszchia sp.), were recorded during the entire annual cycle but were dominant in August (rainy season). Four dinoflagellates (Dinophysis caudata, Gymnodinium catenatum, Margalefidinium polykrikoides, and Phalacroma rotundata), and one cyanobacterium (Trichodesmium erythraeum) (Fig. 8) were also present in April and May. One dinoflagellate species (Noctiluca scintillans) is a vector of toxins, and eight potentially HAB-creating species were found during the dry months (Table 4). 

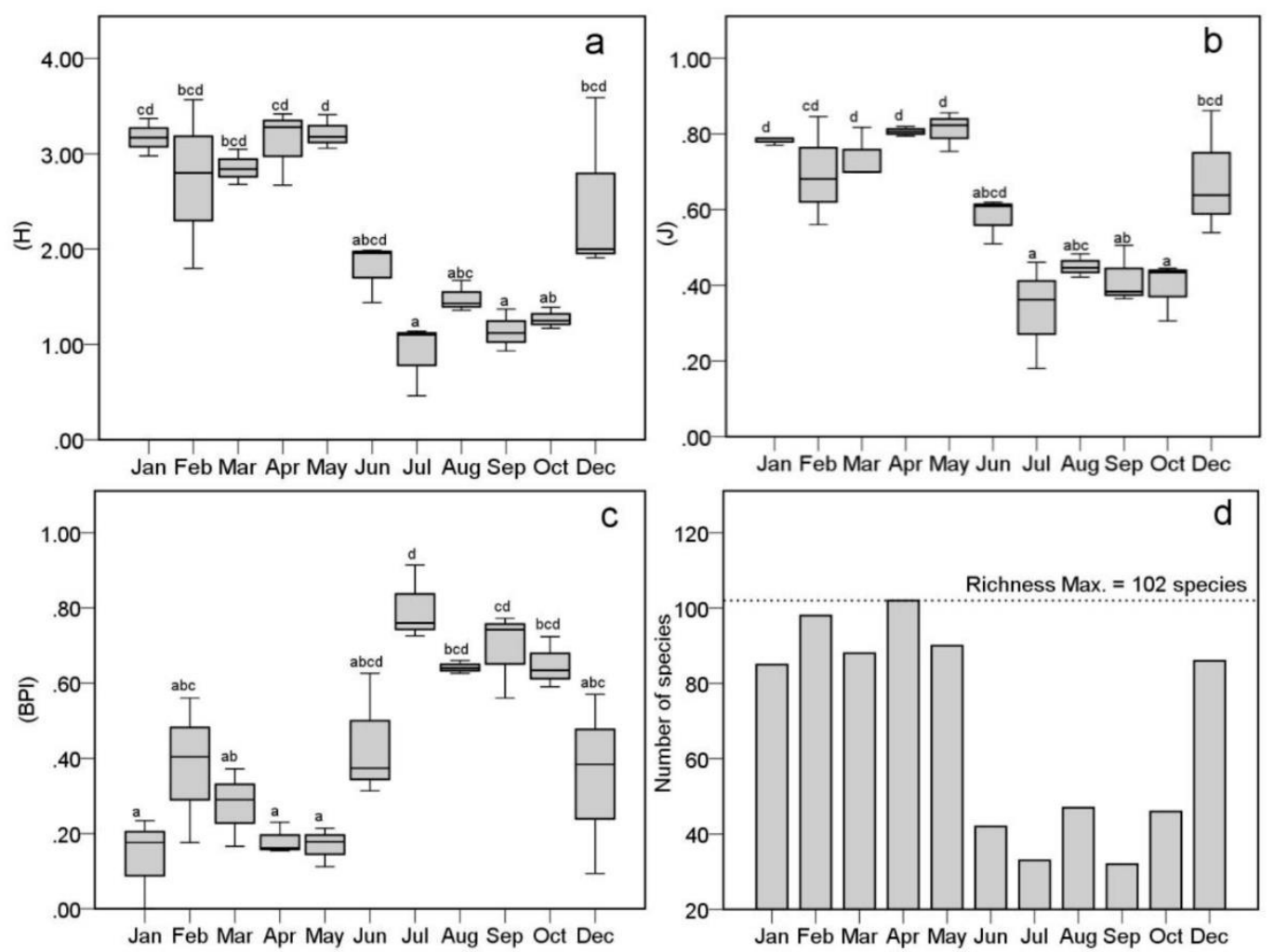

Figure 5. Temporal variability of community marine phytoplankton descriptors in Acapulco Bay. Boxplots of a) ShannonWeaver diversity index $(\mathrm{H})$, b) Pielou equity index $(\mathrm{J})$, c) Berger Parker dominance index (BPI), d) total species richness. The sampling months with the same letter were not significantly different $(P>0.05)$.

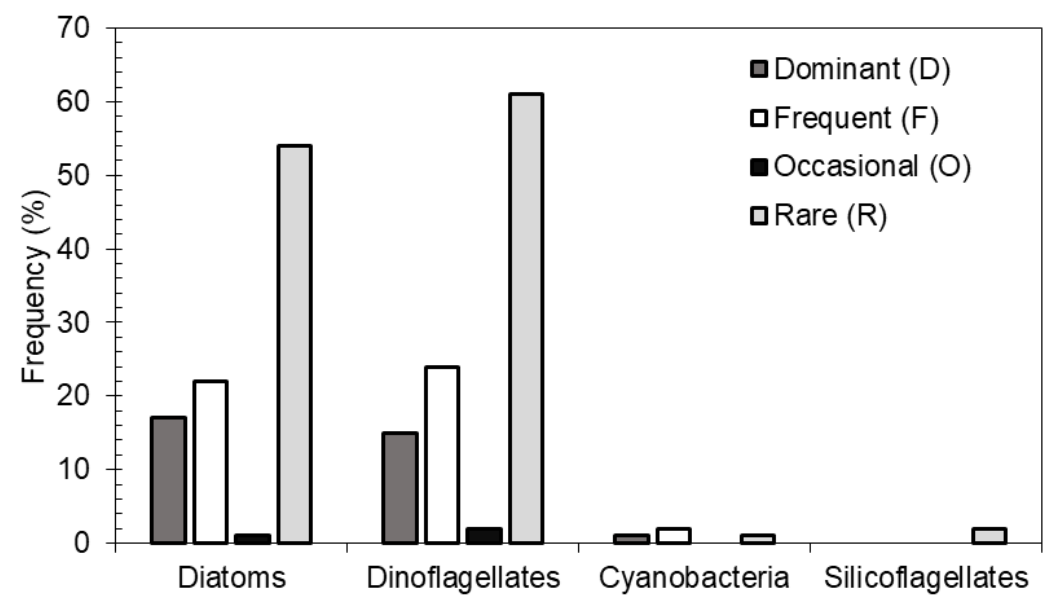

Figure 6. Phytoplankton species classification is based on the frequency-abundance graphic method (Olmstead-Tukey association test).

\section{DISCUSSION}

\section{Environmental variables}

The local environmental variability (temperature, salinity, oxygen, and chlorophyll- $a$ concentration) is a determinant factor to describe the regulation of hydrology and the relationship with the ecological dynamics of several aquatic environments (Pham 2017). The temporal variability in salinity concentrations in this study could be attributed to continental water runoff entering the bay during the rainy season (Rojas-Herrera et al. 2012). The greatest salinity values found in this study (i.e. 33.31-34.06) were associated with the dry season months (January to May). In con- 


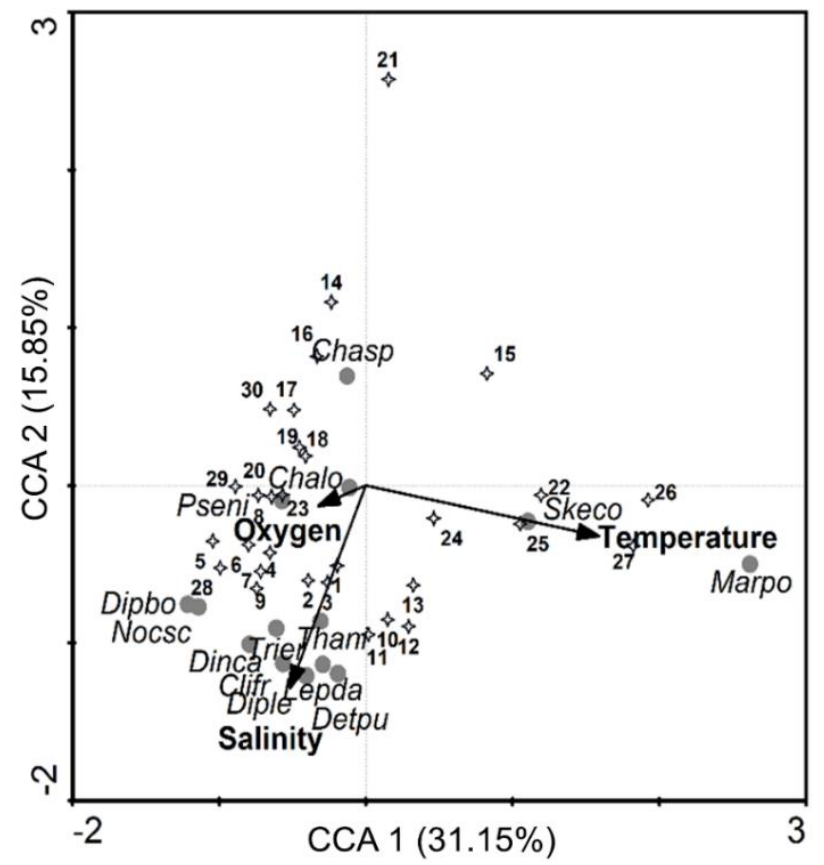

Figure 7. The orthogonal projection of canonical correspondence analysis (CCA) between the dominant temporal species and the physical and chemical variables present in Acapulco Bay. Marpo: Margalefidinium polykrikoides, Skeco: Skeletonema costatum, Detpu: Detonula pumila, Lepda: Leptocylindrus danicus, Diple: Diplopsalis lenticula, Clifr: Climacodium frauenfeldianum, Dinca: Dinophysis caudata, Than: Thalassionema nitzschioides, Nocsc: Noctiluca scintillans, Dipbo: Diplopsalopsis bomba, Pseni: Pseudo-nitzschia sp., Chalo: Chaetoceros lorenzianus, and Chasp: Chaetoceros spp.

trast, low salinities were present during the rainy season (June to December). Low temperatures (i.e. $24.4 \pm 0.26$ to $25.54 \pm 0.15^{\circ} \mathrm{C}$ ) also showed a significant relationship with high chlorophyll- $a$ concentrations $\left(2.56 \pm 0.2\right.$ to $\left.2.73 \pm 0.15 \mu \mathrm{g} \mathrm{L}^{-1}\right)$ and with the greatest species richness (102 species), corresponding to March and April. The high photosynthetic activity could explain this association because low temperatures are linked to low light intensities. Under these conditions, phytoplankton communities increase the amount and variety of pigment molecules, maximizing light absorption during their development (Pal \& Choudhury 2014). The highest oxygen concentrations (91.8 and $100 \%$ ) were recorded in May and December, due to the transition to the winter cold (winter-spring) when oxygen solubility is greatest (Kemker 2013).

The temporality of the environmental variables presented in this study showed a similar pattern reported by Meave del Castillo et al. (2012). They attributed this dynamic to the local upwelling movements and climatic variability in Acapulco Bay during the year (Rojas-Herrera et al. 2012, MorenoDíaz et al. 2015a).

\section{Phytoplankton composition and structure}

The phytoplankton community structure reported in this study is typical of tropical coastal areas (LozaÁlvarez et al. 2018) and was characterized mainly by the great abundance of diatoms (69\%) and dinoflagellates (29\%). Dinoflagellates showed the greatest species richness (101 species), representing $50 \%$ of total richness, and dominated during 6 of the 11 studied months, mainly during the dry season. These results are similar to those reported by Meave-del Castillo et al. (2012), who reported 347 dinoflagellate taxa, corresponding to $54 \%$ of total diversity, and 274 diatom taxa (43\% of total diversity). The dominance of dinoflagellates could be attributed to the fact that they tend to develop in low-turbidity environments (oceanic areas) when hydrodynamics are not affected by meteorological phenomena (Margalef et al. 1979, Smayda \& Reynolds 2001). In contrast, the diatom group responds to more active mixing (high turbidity in coastal areas), to nutrient increases (nitrogen and phosphate), and the presence of silicates, mainly contributed by continental runoff, that are used to create complex cell structures (Mosseri et al. 2008). Silicate structures allow more remarkable floating ability and the possibility of remaining in the water column influenced by mixing processes (Sarthou et al. 2005), which could explain the presence of several opportunist species (Chaetoceros spp., Leptocylindrus danicus, Skeletonema costatum, and Pseudo-nitzschia spp.) during the rainy months (June and August). The other species that showed high relative abundances from January to May (dry season) corresponded to phytoplankton populations' succession in tropical areas (Margalef et al. 1979, Bunse \& Pinhassi 2017, LozaÁlvarez et al. 2018).

The dominance of several species during the studied months evidences the variability in species composition over time. The dinoflagellates Dinophysis caudata, Diplopsalopsis bomba, Diplopsalis lenticula, and Noctiluca scintillans dominated during the dry season (January to May), possibly because they present several types of vertical migration to assimilate nutrients throughout the water column, as well as mixotrophic feeding in some species (De Souza et al. 2014, Stoecker et al. 2017). On the other hand, the presence of the diazotrophic cyanobacterium Trichodesmium erythraeum during the succession of the dry and rainy seasons (April to May) could be indicative of oligotrophic conditions, mainly due to the presence of nitrogen $(\mathrm{N})$ and carbon $(\mathrm{C})$ in Acapulco Bay, as this species can fix nitrogen, which leads to an increase in 


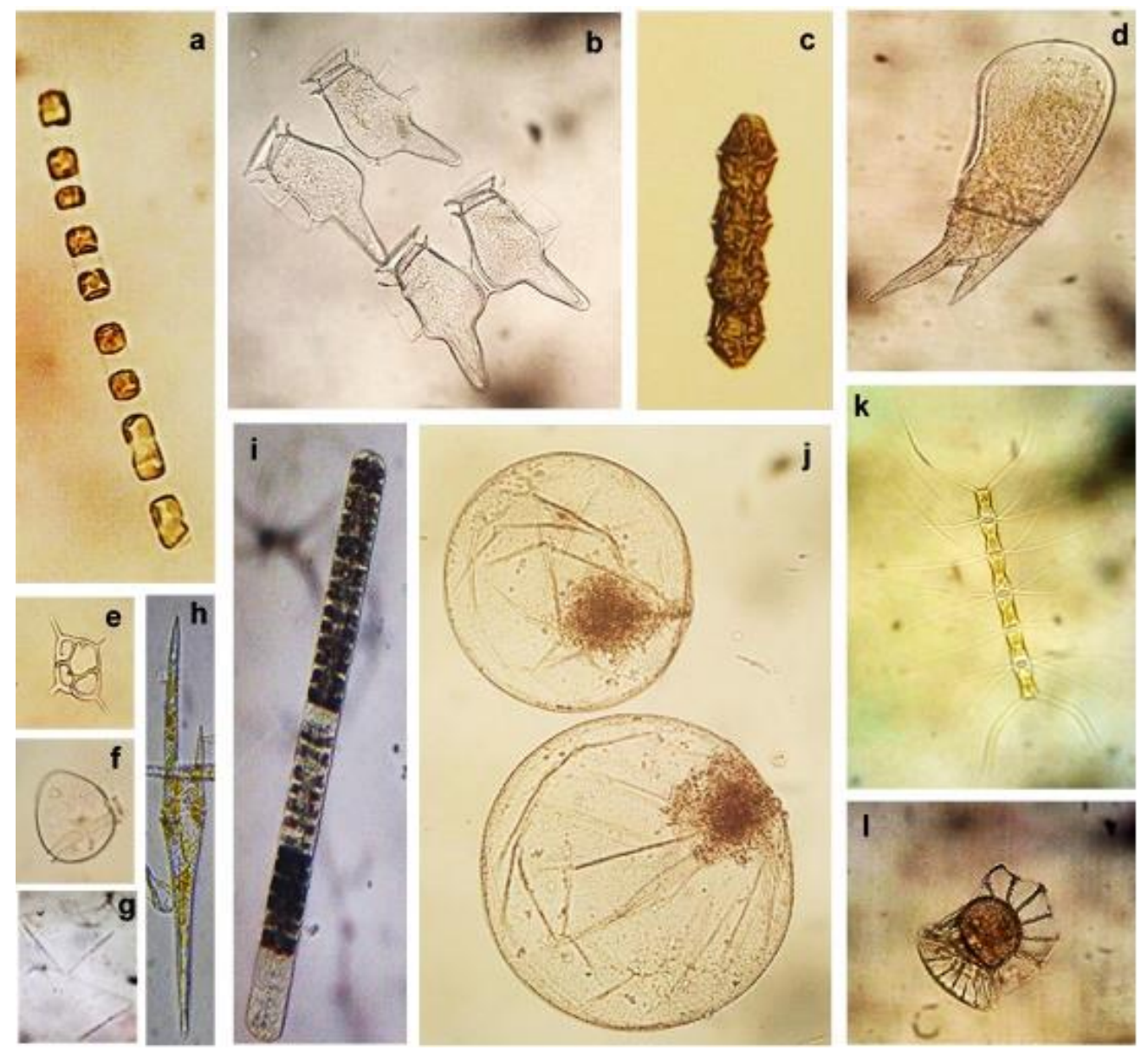

Figure 8. Photographs of some species of phytoplankton present in Acapulco Bay. a) Skeletonema costatum, b) Dinophysis caudata, c) Gymnodinium catenatum, d) Tripos praelongus, e) Dictyocha fibula, f) Phalacroma rotundatum, g) Thalassionema nitzschioides, h) Tripos furca, i) Trichodesmium erythraeum, j) Noctiluca scintillans, k) Chaetoceros sp., l) Ornithocercus thumii. Seen in 40x (a) and 10x (b-1).

its biomass and dominance (LaRoche \& Breitbarth 2005). It also contributes significantly to $\mathrm{C}$ and $\mathrm{N}$ oceanic processes in subtropical and tropical areas (Bar-Zeev et al. 2013). Although macronutrients such as nitrogen were not measured in this study, the previous statements could be supported by what was reported by Rojas-Herrera et al. (2012) and MorenoDíaz et al. (2015b), who observed low nitrogen concentrations in May (0.1 a $0.2 \mathrm{mg} \mathrm{L}^{-1}$, respectively).

Diversity $(H)$ fluctuated from 0.90 to 3.22 during the 2018 annual cycle. The most substantial diversity (3.12-3.22) and species richness (90-102 species) were obtained in April and May, corresponding to the beginning of the spring and dry season. These results are comparable to those documented by Moreno-Díaz et al. (2015a). They reported a diversity of 2.65 in March and of 2.71 in April for the same study area, which could be explained by nutrient limitation during the dry season. The occurrence of opportunist species with fast development is limited (Ahn \& Shanmugam 2006).

In contrast, the presence and dominance of fastgrowth species (e.g. diatoms) that take advantage of nutrients provided by the areas near Acapulco Bay increases during the rainy season. This same pattern was seen with the similarity analysis and nMDS comparing monthly phytoplankton samples, which created three groups with a similarity level of $31 \%$. The first group encompassed January to May samples, with an average richness of 93 species, a high diversity of 3.01 , and low dominance of 0.24 . The second group presented relative abundances of over $60 \%$, encompassing June to December; the average dominance value was higher (0.60), and diversity was low (1.52). Similar patterns have been reported by Rojas-Herrera et al. (2012). They documented the separation of groups between months with greatest precipitation (August to December) and those with low precipitation 
Table 4. Harmful phytoplanktonic species recorded from surface trawls in Acapulco Bay during 2018. *Species with high relative abundance reported in this study.

\begin{tabular}{|c|c|c|}
\hline Species & Harmfulness & Reference \\
\hline \multicolumn{3}{|l|}{ Diatoms } \\
\hline Leptocylindrus danicus* & & Resendiz (2018) \\
\hline \multicolumn{3}{|l|}{ Leptocylindrus minimus } \\
\hline \multicolumn{3}{|l|}{ Cylindrotheca closterium } \\
\hline \multicolumn{3}{|l|}{ Skeletonema costatum* } \\
\hline \multicolumn{3}{|l|}{ Dinoflagellates } \\
\hline Margalefidinium polykrikoides* & $\begin{array}{l}\text { Reactive oxygen species (ROS), neurotoxic } \\
\text { and hemolytic }\end{array}$ & $\begin{array}{l}\text { Chang et al. (1999), Gárate-Lizárraga et al. (2004), } \\
\text { Gobler et al. (2008) }\end{array}$ \\
\hline Gymnodinium catenatum & Paralytic shellfish poisoning (PSP) & Oshima et al. (1993), Bustillos-Guzmán et al. (2012) \\
\hline Dinophysis caudata* & Diarrhetic shellfish poisoning (DSP) & Fernández et al. (2003), Reguera et al. (2012), \\
\hline \multicolumn{3}{|l|}{ Cyanobacteria } \\
\hline Trichodesmium erythraeum ${ }^{*}$ & $\begin{array}{l}\text { Neurotoxins, microcystins, palytoxin, } \\
\text { 42-hydroxy-palytoxin }\end{array}$ & Shaw et al. (2001), Kerbrat et al. (2011) \\
\hline \multicolumn{3}{|l|}{ Silicoflagellates } \\
\hline Dictyocha fibula & Fish-killing & Anderson et al. (2001) \\
\hline
\end{tabular}

(May to July); they also observed pronounced similarity $(70 \%)$ from October to December, with the dominance of diatoms (Pseudo-nitzschia spp. and Leptocylindrus danicus). The third group in this study was associated with a HAB event during October, dominated by the dinoflagellate Margalefidinium polykrikoides, who presented relative abundance levels ranging from 50 to $72.4 \%$ at the $\mathrm{CDO}$ and $\mathrm{PP}$ stations, as well as a diversity of 1.27 , richness of 46 species, and dominance of 0.65 . This month, the absence of $\mathrm{HAB}$ at the MSL station can be explained by the fact that these phenomena can either extend over the entire water body or create random aggregations or patches (Ahn \& Shanmugam 2006). It also explains this sampling station's exclusion from the third group created by the Cluster analysis (Fig. 5). Therefore, $\mathrm{HAB}$ events also influenced the spatiotemporal variability in the phytoplankton community's composition and structure at the local level.

The contribution of rare phytoplankton species constitutes an essential component in population dynamics. Loreau \& Héctor (2001) indicated that rare species are more efficient at acquiring and exploiting resources than some common species in the ecosystem. In this study, the bivariate classification analysis indicated that $58.4 \%$ of species were rare (not frequent or abundant). This condition occurred during 7 of the 11 studied months so that only a certain percentage of the community $(\geq 15 \%)$ influenced the species that produced $\mathrm{HAB}$ in Acapulco Bay. These results are comparable to those reported by Meave del Castillo et al. (2012), who classified over 95\% of phytoplankton species as rare. Likewise, Moreno-Díaz et al. (2015a,b) reported that over $65 \%$ of all species were rare in the bay phytoplankton community, which indicates that Acapulco Bay has an important reserve of genetic, functional, and ecological diversity. Rare species also support ecosystem stability and diversity because they respond rapidly to environmental perturbations, ensuring the growth of different dominant, frequent, or occasional phytoplankton populations (Weithoff 2003, Ignatiades \& Gotsis-Skretas 2013).

The CCA showed that the most important factors that had a significant effect on the dominant species were temperature and salinity, which tend to change marine phytoplankton's structure and productivity (Rojas-Herrera et al. 2012, Thomas et al. 2012, Boyd et al. 2013). It was observed that the diatom Skeletonema costatum was associated with temperatures above $29^{\circ} \mathrm{C}$ in September. This genus has been characterized by rapid growth during spring and summer in tropical environments (Hernández-Becerril et al. 2007, Shikata 
et al. 2008, Meave-del Castillo \& Zamudio-Resendiz 2018), which would explain its appearance and dominance in this month in the bay. Contrary to species such as Chaetoceros lorenzianus, Chaetoceros spp. and Pseudo-nitzschia sp., which showed optimum growth at high oxygen concentrations. Probably due to greater mixing and gas exchange in the water column during the rainy season, which allows greater $\mathrm{CO}_{2}$ availability and assimilation for these diatom species. The carbon fixed is incorporated into their primary metabolism to produce energy for their rapid development in the bay (Smodlaka-Tanković et al. 2018).

\section{Harmful phytoplankton species}

Several marine phytoplankton species, particularly dinoflagellates and diatoms, have been associated with the production of marine toxins and several intoxication events and multiple alterations in the integrity of aquatic ecosystems (Granéli \& Turner 2001, Smayda \& Reynolds 2001, Landsberg 2002). Some HAB species identified in this study (e.g. Gymnodinium catenatum, Trichodesmium erythraeum, among others) coincide with those reported by Gárate-Lizárraga \& MuñetónGómez (2006), López-Cortés et al. (2006, 2015), Gárate-Lizárraga et al. (2007), and Mucino-Márquez et al. (2018) for other locations in the Mexican Pacific. Several diatom species recorded in this study belong to the genus Pseudo-nitszchia; this species dominated during the rainy season, which indicates that at least for the 2018 cycle, this genus' presence in Acapulco Bay was not limited by the temporal variability of physical and chemical factors. Likewise, Rojas-Herrera et al. (2012) and Meave del Castillo \& Zamudio-Resendiz (2018) documented this genus during the rainy season, with relative abundances of 9 to $20 \%$ and a cell concentration of over $300 \times 10^{3}$ cells L $\mathrm{L}^{-1}$. Several species (i.e. Pseudo-nitzschia delicatissima, $P$. pungens, and $P$. pseudodelicatissima) have been reported in Acapulco Bay. Furthermore, although this genus is one of the main producers of domoic acid in marine environments, events related to human intoxication in the area have not yet been reported (Trainer et al. 2012). Further studies should be carried out in Acapulco Bay to identify the factors that allow the subsistence of several species of this genus during the annual cycle.

Of the 17 harmful species identified in the present study, at least three dinoflagellate species have been linked to paralyzing toxins (i.e. Gymnodinium catenatum) and diarrhea-causing toxins (Dinophysis caudata and Phalacroma rotundata) (Hallegraeff et al. 2003, FAO \& WHO 2016). The dinoflagellate Margalefidinium polykrikoides have been associated with harmful effects in aquatic ecosystems, including hemolytic and allelopathic activity and production of oxygen reactive species (Tang \& Glober 2010, Lim et al. 2014). In this study, M. polykrikoides dominated in October with a relative abundance above $65 \%$ linked to the maximum temperatures recorded $\left(34.61 \pm 1.83^{\circ} \mathrm{C}\right)$. However, $M$. polykrikoides is potentially harmful and has been recorded over several years in Acapulco Bay (Meave del Castillo \& Zamudio-Resendiz, 2018). Previous studies in the Mexican Pacific indicate that this species has had a limited presence during the rainy season due to its relationship with high nutrient inputs from the continental area (López-Cortés et al. 2019). However, the physiological mechanisms that ensure permanence and biomass increase are still unknown (Kim et al. 2002, Thoha et al. 2019).

Results show that the composition of the structure of the phytoplankton community of Acapulco Bay varied temporally during the 2018 annual cycle. Temperature and salinity were the main environmental factors that affected dynamics. However, they were also influenced by the rainy and dry seasons, with marked pulses of primary production during spring and summer. Moreover, the appearance of harmful species (e.g. M. polykrikoides) in the Mexican Pacific has been limited to short-term events, recurring seasonal phenomena, and rare events related to exceptional climatic conditions, such as the El Niño and La Niña phenomena (Meave del Castillo \& Zamudio-Resendiz 2018, López-Cortés et al. 2019). Therefore, the composition and structure of phytoplankton in Acapulco Bay is a good indicator of coastal water masses linked to several events (e.g. climate change and increase in terrestrial activities) that influence these ecosystems at the local level. The continuous monitoring of coastal areas with economic activities is important to follow events caused by several HAB-producing species to predict their adverse effects on public health and the stability of tropical marine ecosystems.

\section{ACKNOWLEDGMENTS}

We thank the Consejo Nacional de Ciencia y Tecnología (CONACyT) for the scholarship granted to VACU (CVU: 868203) for postgraduate studies and external reviewers for their observations to improve this manuscript.

\section{REFERENCES}

Ahn, Y.H. \& Shanmugam, P. 2006. Detecting the red tide algal blooms from satellite ocean color observations in optically complex Northeast-Asia coastal waters. Remote Sensing of Environment, 103: 419-437.

Anderson, M.J. 2001. A new method for non-parametric multivariate analysis of variance. Austral Ecology, 26: 32-46. 
Anderson, D.M., Andersen, P., Bricelj, V.M., Cullen, J.J. \& Rensel, J.E. 2001. Monitoring and management strategies for harmful algal blooms in coastal waters. Asia Pacific Economic Program APEC \#201-MR01.1, Singapore, and Intergovernmental Oceanographic Commission Technical Series, 59, Paris.

Balech, E. 1988. Los dinoflagelados del Atlántico Sudoccidental. Publicaciones Especiales, Instituto Español de Oceanografía, 1: 1-310.

Bar-Zeev, E., Avishay, I., Bidle, K.D. \& Berman-Frank, I. 2013. Programmed cell death in the marine cyanobacterium Trichodesmium mediates carbon and nitrogen export. ISME Journal, 7: 2340-2348. doi: 10.1038/ ismej.2013.121

Boyd, P.W, Rynearson, T.A., Armstrong, E.A., Fu, F., Hayashi, K., Hu, Z., et al. 2013. Marine phytoplankton temperature versus growth responses from Polar to Tropical waters - outcome of a scientific communitywide study. Plos One, 8: e63091. doi: 10.1371/journal. pone.0063091

Bunse, C. \& Pinhassi, J. 2017. Marine bacterioplankton seasonal succession dynamics. Trends in Microbiology, 25: 494-505. doi: 10.1016/j.tim.2016.12.013

Bustillos-Guzmán, J.J, Band-Schmidt, C.J, López-Cortés, D.J, Gárate-Lizárraga, I., Núñez-Vázquez, E.J. \& Hernández-Sandoval, F.E. 2012. Variaciones en el crecimiento y toxicidad en Gymnodinium catenatum Graham del golfo de California bajo diferentes proporciones de nitrógeno y fósforo. Ciencias Marinas, 38: 101-117.

Carreto-Iraurgui, J.I. 1989. Mareas rojas. Ciencia Hoy, 1: 73-82.

Chang, S.K., Lee, S.G., Lee, C.K., Kim, H.G. \& Jung, J. 1999. Reactive oxygen species as causative agents in the icthyotoxicity of red tide dinoflagellate Cochlodinium polykrikoides. Journal Plankton Research, 21: 21052115. doi: 10.1093/plankt/21.11.2105

Comisión Nacional para el Conocimiento y Uso de la Biodiversidad (CONABIO). 2007. Análisis de vacíos y omisiones en conservación de la biodiversidad marina de México: océanos, costas e islas. CONABIO, CONANP, The Nature Conservancy Programa México, Pronatura, A.C. Ciudad de México.

Cupp, E. 1943. Marine plankton diatoms of the west coast of North America. Bulletin of the Scripps Institution of Oceanography, 5: 1-237.

De Souza, K.B., Jephson, T., Hasper, T.B. \& Carlsson, P. 2014. Species-specific dinoflagellate vertical distribution in temperature-stratified waters. Marine Biology, 161: 1725-1734. doi: 10.1007/s00227-0142446-2
Escalera, L., Pazos, Y., Moroño, Á. \& Reguera, B. 2007. Noctiluca scintillan may act as a vector of toxigenic microalgae. Harmful Algae, 6: 317-32. doi: 10.1016/j. hal.2006.04.006

Falkowski, P.G. \& Raven, J.A. 2007. Aquatic photosynthesis. Princeton University Press, Oxford.

Food and Agriculture Organization (FAO) \& World Health Organization (WHO). 2016. Technical paper on toxicity equivalency factors for marine biotoxins associated with bivalve molluscs. FAO, Rome, 108 pp.

Fernández, M.L., Míguez, A., Martínez, A., Moroño, A., Arévalo, F., Pazos, Y., et al. 2003. First report of Pectenotoxin-2 in phytoplankton net-hauls and mussels from the Galician Rías Baixas (NW Spain) during proliferations of Dinophysis acuta and Dinophysis caudata. In: Villalba, A., Reguera, B., Romalde, J. \& Beiras, R. (Eds.). Molluscan shellfish safety. Consellería de Pesca e Asuntos Marítimos da Xunta de Galicia and Intergovernmental Oceanographic Commission of UNESCO, Santiago de Compostela.

Fogg, G.E. 2001. Algal adaptation to stress - some general remarks. In: Rai, L.C. \& Gaur, J.P. (Eds.). Algal adaptation to environmental stresses. Springer-Verlag, Berlin.

France, J. \& Mozetič, P. 2006. Ecological characterization of toxic phytoplankton species (Dinophysis spp., Dinophyceae) in Slovenian mariculture areas (Gulf of Trieste, Adriatic Sea) and the implications for monitoring. Marine Pollution Bulletin, 52: 1504-1516. doi: 10.1016/j.marpolbul.2006.05.012

Gárate-Lizárraga, I. \& Muñetón-Gómez, M.S. 2006. Florecimiento del dinoflagelado Gonyaulax polygramma frente a la Isla Espíritu Santo, Golfo de California México. Revista de Investigaciones Marinas, 27: 31-39.

Gárate-Lizárraga, I., Arellano-Martínez, B., Ceballos Vázquez, P., Bustillos-Guzmán, J., López-Cortés, D. \& Hernández-Sandoval F. 2004. Fitoplancton tóxico y presencia de toxinas paralizantes en la almeja mano de león (Nodipecten subnodosus, Sowerby, 1835) en la Bahía de Los Ángeles, B.C. Resúmenes del II Taller Phytoplankton community in tuna farms in the Bahía de La Paz 1023 sobre florecimientos algales nocivos, Ensenada, B.C., 20 pp.

Gárate-Lizárraga, I. \& Muñetón-Gómez, M.S. 2008. Bloom of Peridinium quinquecorne Abé in $\mathrm{La}$ Ensenada de La Paz, Gulf of California (July 2003). Acta Botanica Mexicana, 83: 33-47.

Gárate-Lizárraga, I. \& Muñetón-Gómez, M.S. 2009. Primer registro de la diatomea epibionte Pseudohimantidium pacificum y de otras asociaciones simbióticas en el Golfo de California. Acta Botánica Mexicana, 88: 33-47. 
Gárate-Lizárraga, I., Okolodkov, Y.B. \& CortésAltamirano, R. 2016. Microalgas formadoras de florecimientos algales en el Golfo de California. In: García-Mendoza, E., Quijano-Scheggia, S.I., OlivosOrtiz, A. \& Núñez-Vázquez, E.J. (Eds.). Florecimientos algales nocivos en México. CICESE, Ensenada.

Gárate-Lizárraga, I., López-Cortés, D.J., BustillosGuzmán, J.J. \& Fernández-Sandoval, F. 2004. Blooms of Cochlodinium polykrikoides (Gymnodiniaceae) in the Gulf of California, Mexico. Revista de Biología Tropical, 52: 51-58.

Gárate-Lizárraga, I., Sevilla-Torres, G., Álvarez-Añorve, M., Aguirre-Bahena, F., Violante-González, J. \& Rojas-Herrera, A.A. 2013. First record of a red tide caused by Gyrodinium instriatum (Dinophyceae: Gymnodiniales) in Bahía de Acapulco, Guerrero. Oceánides, 28: 43-47.

Gárate-Lizárraga, I., Díaz-Ortiz, J.A., Pérez-Cruz, B., Alarcón-Tacuba, M., Torres-Jaramillo, A., AlarcónRomero, M.A. \& López-Silva, S. 2009. Cochlodinium polykrikoides and Gymnodinium catenatum in Bahía de Acapulco, Mexico (2005-2008). Harmful Algae News, 40: 8-9.

Gobler, C.J., Berry, D.L., Anderson, O.R., Burson, A., Koch, F., Rodgers, B.S., et al. 2008. Characterization, dynamics, and ecological impacts of harmful Cochlodinium polykrikoides blooms on eastern Long Island, NY, USA. Harmful Algae, 7: 293-307. doi: 10.1016/j.hal.2007.12.006

Granéli, E. \& Turner, J.T. 2001. Ecology of harmful algae. Springer, Kalmar.

Granéli, E. \& Turner, J.T. 2006. Ecology of harmful algae. Springer-Verlag, Heidelberg.

Griffith, A.W. \& Gobler, C.J. 2020. Harmful algal blooms: a climate change co -stressor in marine and freshwater ecosystems. Harmful Algae, 91: 101590. doi: 10.1016/j.hal.2019.03.008

Hallegraeff, G.M., Anderson, D.M. \& Cembella, A.D. 2003 Manual on harmful marine microalgae. UNESCO, Paris.

Hasle, G.R. \& Syvertsen, E.E. 1996. Marine diatoms. In: Tomas, C.R. (Ed.). Identifying marine phytoplankton. Academic Press, San Diego.

Hasle, G.R. 2002. Are most of the domoic acid-producing species of the diatom genus Pseudo-nitzschia cosmopolites? Harmful Algae, 1: 137-146. doi: 10.1016/S 1568-9883(02)00014-8

Hernández-Becerril, D.U. 2014. Biodiversidad de algas planctónicas marinas (Cyanobacteria, Prasinophyceae, Euglenophyta, Chrysophyceae, Dictyochophyceae, Eustigmatophyceae, Parmophyceae, Raphidophyceae, Bacillariophyta, Cryptophyta, Haptophyta, Dinoflagellata) en México. Revista Mexicana de Biodiversidad, 85: 44-53.
Hernández-Becerril, D.U., Bravo-Sierra, E. \& AkéCastillo, J. 2007. Phytoplankton on the western coasts of Baja California in two different seasons in 1998. Scientia Marina, 71: 735-743.

Ignatiades, L. \& Gotsis-Skretas, O. 2013. The contribution of rare species to coastal phytoplankton assemblages. Marine Ecology, 35: 132-145.

Kemker, C. 2013. Oxígeno disuelto fundamentos de las mediciones ambientales. Fondriest Environmental, Ohio.

Kerbrat, A.S., Amzil, Z., Pawlowiez, R., Golubic, S., Sibat, M., Darius, H.T., et al. 2011. First evidence of palytoxin and 42-hydroxy-palytoxin in the marine cyanobacterium Trichodesmium. Marine Drugs, 9: 543-560. doi: 10.3390/md9040543

Kim, D., Oda, T., Muramatsu, T., Kim, D., Matsuyama, Y. \& Honjo, T. 2002. Possible factors responsible for the toxicity of Cochlodinium polykrikoides, a red tide phytoplankton. Comparative Biochemistry and Physiology - Part C: Toxicology \& Pharmacology, 132: 415-423. doi: 10.1016/S1532-0456(02)00093-5

Landsberg, J.H. 2002. The effects of harmful algal blooms on aquatic organisms. Reviews in Fisheries Science, 10: 113-390. doi: 10.1080/20026491051695

LaRoche, J. \& Breitbarth, E. 2005. Importance of the diazotrophs as a source of new nitrogen in the ocean. Journal of Sea Research, 53: 67-91. doi: 10.1016/j. seares.2004.05.005

Licea-Durán, S., Moreno-Ruiz, J.L., Santoyo-Reyes, H. \& Figueroa, G. 1995. Dinoflageladas del Golfo de California. Universidad Autónoma de Baja California Sur, SEP-FOMES, PROMARCO, Ciudad de México.

Lim, A.S., Jeong, H.J., Jang, T.Y., Jang, S.H. \& Franks, P.J.S. 2014. Inhibition of growth rate and swimming speed of the harmful dinoflagellate Cochlodinium polykrikoides by diatoms: implications for red tide formation. Harmful Algae, 37: 53-61. doi: 10.1016/ j.hal.2014.05.003

López-Cortés, D.J., Bustillos-Guzmán, J.J. \& GárateLizárraga, I. 2006. Inusual mortality of krill (Crustacea: Euphausiacea) in Bahía de La Paz, Gulf of California. Pacific Science, 60: 235-342.

López-Cortés, D.J., Núñez-Vázquez, E.J., Band-Schmidt, C.J., Gárate-Lizárraga, I., Hernández-Sandoval, F.E. \& Bustillos-Guzmán, J.J. 2015. Mass fish die-off during a diatom bloom in the Bahía de La Paz, Gulf of California. Hidrobiológica, 25: 39-48.

López-Cortés, D.L., Núñez-Vázquez, E., DorantesAranda, J., Band-Schmidt, C.J., Hernández-Sandoval, F.E., Bustillos-Guzmán, J.J., et al. 2019. The state of knowledge of harmful algal blooms of Margalefidinium polykrikoides (a.k.a. Cochlodinium polykricoides) in Latin America. Frontiers in Marine Science, 6: 463. 
Loreau, M. \& Hector, A. 2001. Partitioning selection and complementarity in biodiversity experiments. Nature, 412: 72-76.

Loza-Álvarez, S., Benavides-Morera, R., Brenes-Rodriguez, C. \& Ballestero-Saxon, D. 2018. Estructura del fitoplancton en las épocas seca y lluviosa en el golfo de Papagayo, Costa Rica. Revista Ciencias Marinas y Costeras, 10: 9-30. doi: 10.15359/revmar.10-2.1

Magurran, A.E. 2004. Measuring biological diversity. Blackwell Science, Oxford.

Margalef, R. 1981. Ecología. Editorial Planeta, Barcelona.

Margalef, R., Estrada, M. \& Blasco, D. 1979. Functional morphology of organisms involved in red tides, as adapted to decaying turbulence. In Taylor, D. \& Seliger, H. (Eds.). Toxic dinoflagellate blooms. Elsevier, New York, pp. 89-94.

Mayo-Vera, A.B. 2004. Estudio ambiental de la Bahía de Acapulco, Guerrero. Tesis de Licenciatura, Universidad Nacional Autónoma de México, Ciudad de México, 76 pp.

Meave del Castillo, M.E. \& Zamudio-Resendiz, M.E. 2018. Planktonic algal blooms from 2000 to 2015 in Acapulco Bay, Guerrero, Mexico. Acta Botánica Mexicana, 125: 61-93. doi: 10.21829/abm125.2018. 1316

Meave del Castillo, M.E., Zamudio-Resendiz, M.E. \& Castillo-Rivera, M. 2012. Riqueza fitoplanctónica de la Bahía de Acapulco y zona costera aledaña, Guerrero, México. Acta Botanica Mexicana, 100: 405487. doi: 10.21829/abm100.2012.41

Moestrup, Ø., Akselmann-Cardella, R., Fraga, S., Hoppenrath, M., Iwataki, M., Komárek, J., et al. (Eds.). 2019. IOC-UNESCO taxonomic reference list of harmful micro algae. [http://www.marinespecies.org/hab]. Reviewed: August 28, 2019.

Moreno, J.L., Licea, S. \& Santoyo, H. 1996. Diatomeas del Golfo de California. Universidad Autónoma de Baja California Sur, La Paz.

Moreno-Díaz, G., Rojas-Herrera, A.A., GonzálezGonzález, J., Violante-González, J., Rosas-Acevedo, J.L. \& García-Ibañez, S. 2015b. Temporal variation in the abundance and composition of phytoplankton species, collected with net in the Acapulco Bay, Mexico. Revista BioCiencias, 3: 88-102.

Moreno-Díaz, G., Rojas-Herrera, A., Violante-González, J., González-González, J., Acevedo, J. \& GarcíaIbáñez, S. 2015a. Temporal variation in composition and abundance of phytoplankton species during 2011 and 2012 in Acapulco Bay, Mexico. Open Journal of Marine Science, 5: 358-367. doi: 10.4236/ojms.2015. 53029

Mosseri, J., Quéguiner, B., Armand, L. \& CornetBarthaux, V. 2008. Impact of iron on silicon utilization by diatoms in the Southern Ocean: a case study of Si/N cycle decoupling in a naturally iron-enriched area. Deep-Sea Research Part II: Topical Studies in Oceanography, 55: 801-819.

Mucino-Márquez, R.E., Gárate-Lizárraga, I., LópezCortés, D.J., Bustillos-Guzmán, J.J. \& HernándezSandoval, F.E. 2018. Seasonal variation of the phytoplankton community in tuna farms in Bahía de La Paz, southern Gulf of California, Mexico. Latin American Journal of Aquatic Research, 46: 10111024.

Oshima, Y., Blackburn, S.I. \& Hallegraeff, G.M. 1993. Comparative study on paralytic shellfish toxin profiles of the dinoflagellate Gymnodinium catenatum from three different countries. Marine Biology, 116: 471476.

Pal, R. \& Choudhury, A.K. 2014. An introduction to phytoplanktons: diversity and ecology. Springer, Berlin.

Pham, T.L. 2017. Environmental gradients regulate the spatio-temporal variability of phytoplankton assemblages in the Can Gio Mangrove Biosphere Reserve, Vietnam. Ocean Science Journal, 52: 537-547.

Pielou, E.C. 1969. An introduction to mathematical ecology. Wiley, New York.

Pizarro, G., Paz, B., González-Gil, S., Franco, J.M. \& Reguera, B. 2009. Seasonal variability of lipophilic toxins during a Dinophysis acuta bloom in western Iberia: differences between picked cells and plankton concentrates. Harmful Algae, 8: 926-937. doi: 10.1016/j.hal.2009.05.004

Rao, D.V.S., Quilliam, M.A. \& Pocklington, R. 1988. Domoic acid - a neurotoxic amino acid produced by the marine diatom Nitzschia pungens in culture. Canadian Journal of Fisheries and Aquatic Sciences, 45: 2076-2079. doi: 10.1139/f88-241

Reguera, B., Velo-Suárez, L., Raine, R. \& Gil-Park, M. 2012. Harmful Dinophysis species: a review. Harmful Algae, 14: 87-106. doi: 10.1016/j.hal.2011.10.016

Reynolds, C.S. 1989. Physical determinants of phytoplankton succession. In: Sommer, U. (Ed.). Plankton ecology. Springer, Berlin.

Rojas-Herrera, A.A., Violante-González, J., GarcíaIbáñez, S., Sevilla-Torres, V.M.G., Gil-Guerrero, J.S. \& Flores-Rodríguez, P. 2012. Temporal variation in the phytoplankton community of Acapulco Bay, Mexico. Microbiology Research 3: 13-19. doi: 10.4081/mr.2012.e4

Sarthou, G., Timmermans, K.R., Blain, S. \& Tréguer, P. 2005. Growth physiology and fate of diatoms in the ocean: a review. Journal of Sea Research, 53: 25-42. doi: 10.1016/j.seares.2004.01.007

Shaw, G., Poon, K., Codd, G., O'Neil, J., Lam, P.K.S., Chong, M., et al. 2001. The presence of microcystinlike compounds in blooms of the marine cyanobac- 
terium, Trichodesmium spp. 5th International Conference on Toxic Cyanobacteria (ICTC V), Noosa, Queensland, Australia. CSIRO, Clayton.

Shayestehfar, A., Noori, M. \& Shirazi, F. 2010. Environmental factor effects on the seasonally changes of zooplankton density in Parishan Lake (Khajoo Spring Site), Iran. Asian Journal of Experimental Biological Sciences, 1: 840-844.

Shevchenko, O.G., Shulkin, V.M. \& Ponomareva, A.A. 2018. Phytoplankton and hydrochemical parameters near net pens with beluga whales in a shallow bay of the northwestern Sea of Japan. Thalassa: An International Journal of Marine Sciences, 34: 139-151. doi: 10.1007/s41208-017-0046-X

Shikata, T., Nagasoe, S., Matsubara, T., Yoshikawa, S., Yamasaki, Y.N., Shimasaki, Y., et al. 2008. Factors influencing the initiation of blooms of the raphidophyte Heterosigma akashiwo and the diatom Skeletonema costatum in a port in Japan. Limnology and Oceanography, 53: 2503-2518. doi: 10.4319/lo. 2008.53.6.2503

Smayda, T.J. \& Reynolds, C.S. 2001. Community assembly in marine phytoplankton: application of recent models to harmful dinoflagellate blooms. Journal of Plankton Research, 23: 447-461. doi: 10.1093/plankt/23.5.447

Smodlaka-Tanković, M., Baričević, A., Ivančić, I., Kužat, N., Medić, N., Pustijanac, E., et al. 2018. Insights into the life strategy of the common marine diatom Chaetoceros peruvianus Brightwell. Plos One, 13: e0203634. doi: 10.1371/journal.pone.0203634

Stoecker, D.K., Hansen, P.J., Caron, D.A. \& Mitra, A. 2017. Mixotrophy in the marine plankton. Annual Review of Marine Science, 9: 311-335.

Received: 10 March 2020; Accepted: 1 October 2020
Tang, Y.Z. \& Gobler, C.J. 2010. Allelopathic effects of Cochlodinium polykrikoides isolates and blooms from the estuaries of Long Island New York on co-occurring phytoplankton. Marine Ecology Progress Series, 406: 19-31. doi: 10.3354/meps08537

Thoha, H., Muawanah, Bayu-Intan, M.D., Rachman, A., Sianturi, O.R., Sidabutar, T., et al. 2019. Resting cyst distribution and molecular identification of the harmful dinoflagellate Margalefidinium polykrikoides (Gymnodiniales, Dinophyceae) in Lampung Bay, Sumatra, Indonesia. Frontiers in Microbiology, 10: 306. doi: 10.3389/fmicb.2019.00306

Thomas, M.K., Kremer, C.T., Klausmeier, C.A. \& Litchman, E. 2012. A global pattern of thermal adaptation in marine phytoplankton. Science, 338: 1085-1088. doi: 10.1126/science. 1224836

Throndsen, J. 1997. The planktonic marine flagellates. In: Tomas, C.R. (Ed.). Identifying marine phytoplankton. Academic Press, San Diego.

Trainer, V.L., Bates, S.S., Lundholm, N., Thessen, A.E., Cochlan, W.P., Adams, N.G. \& Trick, C.G. 2012. Pseudo-nitzschia physiological ecology, phylogeny, toxicity, monitoring, and impacts on ecosystem health. Harmful Algae, 14: 271-300. doi: 10.1016/j.hal.2011. 10.025

Vila, M. \& Masó, M. 2005. Phytoplankton functional groups and harmful algal species in anthropogenically impacted waters of the NW Mediterranean Sea. Scientia Marina, 69: 31-45.

Weithoff, G. 2003. The concepts of 'plant functional types' and 'functional diversity' in lake phytoplankton a new understanding of phytoplankton ecology? Freshwater Biology, 48: 1669-1675.

Zar, J.H. 1999. Biostatistical analysis. Prentice-Hall, New Jersey. 